\title{
DIGITAL COMPETENCIES IN PROCESS OF CREATING THE KNOWLEDGE COMPANY IN CONSTRUCTION SECTOR
}

\author{
František Mesároš \\ VÚSI, Košice, SK \\ fmesaros@vusi.sk \\ Peter Mesároš \\ University of Economics, Bratislava, SK \\ pmesaros@vusi.sk
}

\begin{abstract}
This study is focused on core competencies for lifelong learning for the knowledge society, especially on the digital competence. The aim of study is twofold. First, to examine the level of the digital competence in sample of graduate university students. Second, to give a proposal of procedure for measuring the level of competence in construction company. The results of research concerning the digital competence showed the subnormal level of this competence in graduate university students. The procedure for measuring the level of competence was done. It represent a model which can be useful for construction companies.
\end{abstract}

KEYWORDS: key competencies, digital competence, measurement

\section{INTRODUCTION}

At a time when governments face the challenges of maintaining competitiveness in a global economy, it is necessary to have high-quality comparative information regarding the key competencies of the adult population. The reason is to have sufficient amount of information that can help governments to evaluate policies and design more effective intervention. Education Council (2006) has stressed the importance of key competencies for lifelong learning.

Competence can be seen as a combination of an individual's knowledge and task requirements; a good fit indicates higher levels of competence. Competence can be seen as specific for different disciplines, jobs, or functions.

\section{A digital competence in university students}

Authors analyze the level of digital competence which represents a key competence for knowledge society. This empirical study is a part of project aimed to reveal the key competencies of university students for the knowledge society. The main aim of pilot study was to identify which competencies and skills and how the graduates possess.

Pilot study was conducted on a random sample of 300 graduate students of economic, philosophical and technical specialization. We have decided to test three of core cognitive competencies: digital, verbal, and mathematical competence. We have also analyzed the gender differences in cognitive competencies. We have postulated the theoretical background 
in our previous study M. Mesárošová, F. Mesároš, P. Mesároš (2009a). We have examined the three cognitive competencies in other study (M. Mesárošová, F. Mesároš, P. Mesároš; 2009b).

\section{Sample}

The target group of graduates of university students in our research project represented a random sample consisting of 300 students. The composition of the sample in terms of field of study was as follows: 100 students of philosophical specialization, 100 students of economic direction and 100 technical students. The composition of the sample according to gender was almost balanced $-58.7 \%$ women, $41.3 \%$ of men. The average age was 23.47 years, the standard deviation of 1.33 (range: 21 to 34 years).

\section{Method}

\section{Test of digital competence}

As a test, we used digital competence IT Fitness test falling within the activities week, e-Skills in Europe in 2010, which constructed a team of the Faculty of Mathematics, Physics and Informatics, Comenius University in Bratislava under the direction of Z. Kubincová (http://www.eskills.sk/). This test was intended to probe digital skills and practical skills in information technology on-line. Four online versions of IT Fittness test have been published each of them included the 24 questions. IT Fittness test enabled to work online and also search for relevant information online. It was focused on theoretical knowledge and practical skills, as well as it provided an immediate opportunity to learn the percentage score, which was the basis for our analysis. More than 50000 persons take a participation in this online test of digital competence with an average success rate of $39 \%$. Students participated in our study tested online their own digital competence (information capacity) and provide their percentage score.

\section{Methods of data analysis}

Statistical analysis was performed by means of analysis of variance (ANOVA). The parametric and nonparametric variant of ANOVA was used. Descriptive statistics methods such as correlation and central tendencies were used to characterize the relationships among variables.

\section{Results}

\section{Analysis of cognitive competencies}

In evaluating the level of cognitive competencies we have reached in our study to the conclusion that the overall level of competencies is low. Probe into three core competencies has shown the below average level of these skills: digital, mathematical, on the one hand, and above-average level of verbal skills (M. Mesárošová, F. Mesároš, P. Mesároš; 2009b). The lowest performance was recorded in a group of students of philosophical and technical specialization for mathematical competence, the relatively balanced performance was in test of verbal skills, in which dominated students of philosophical specialization. Few, however, were able to benefit from their existing knowledge, practical skills in digital competence test (Table 1). Students of economic specialization have achieved the highest performance in digital competencies test in comparison to the low performance of women studying philosophy 
departments. In contrast, verbal competence dominated in students of the philosophical direction. Technically oriented students attained average achievement in the three cognitive tests. In summary, we have found that the most developed mathematical and digital competencies have students of economics; above average verbal competence was seen in the philosophical students.

Table 1 Arithmetical Mean and Median values of the digital competence

\begin{tabular}{|c|c|c|c|c|c|c|c|c|c|c|c|c|}
\hline & \multicolumn{4}{|c|}{ Economical specialization } & \multicolumn{4}{|c|}{$\begin{array}{l}\text { Philosophical } \\
\text { specialization }\end{array}$} & \multicolumn{4}{|c|}{ Technical specialization } \\
\hline & men & & wom & & men & & wom & & men & & wome & \\
\hline & $\mathrm{AM}^{1}$ & $\mathrm{Me}^{2}$ & AM & $\mathrm{Me}$ & AM & $\mathrm{Me}$ & AM & $\mathrm{Me}$ & AM & $\mathrm{Me}$ & AM & $\mathrm{Me}$ \\
\hline $\begin{array}{l}\text { Average } \\
\text { Grade }\end{array}$ & 2,34 & 2,38 & 2,05 & 2,00 & 1,63 & 1,70 & 1,55 & 1,45 & 1,96 & 2,00 & 1,92 & 1,75 \\
\hline $\begin{array}{l}\text { Digital } \\
\text { Competency }\end{array}$ & $\begin{array}{l}64,3 \\
3\end{array}$ & $\begin{array}{l}70,5 \\
0\end{array}$ & $\begin{array}{l}51,4 \\
8\end{array}$ & $\begin{array}{l}50,0 \\
0\end{array}$ & $\begin{array}{l}48,3 \\
3\end{array}$ & $\begin{array}{l}54,0 \\
0\end{array}$ & $\begin{array}{l}36,7 \\
3\end{array}$ & $\begin{array}{l}32,0 \\
0\end{array}$ & $\begin{array}{l}41,6 \\
8\end{array}$ & $\begin{array}{l}40,5 \\
0\end{array}$ & $\begin{array}{l}41,3 \\
3\end{array}$ & $\begin{array}{l}36,0 \\
0\end{array}$ \\
\hline
\end{tabular}

${ }^{1} \mathrm{AM}$ - arithmetic mean; ${ }^{2} \mathrm{Me}-$ median

The frequency of performance in digital competence according to the study specialization and gender

More detailed information on the level of digital competence in terms of frequency provides a break down of performance in this cognitive skill to four sub-categories: significantly below average, below average, average, above average performance on the basis of percentile data. The whole sample in is shifted to below-average performance. Digital competence is an example of weakly developed cognitive competency - up to $60 \%$ of students belong to the group with significantly below-average and below-average performance. Median value of the sample reaches 44 , meaning that this value achieved or scored below $50 \%$ of students in our sample. Nationwide average in IT Fittness test was recorded value of approximately 39\%. Our graduate students scored only slightly above this value, which is considered to be as "apprentice" level by the creators of the test (Skills in 2010). In the group of the students of philosophical specialization $79 \%$ belonged to the category of bellow average performers, contrary to economic students, which performance varied in the range of the average to above average $(57 \%)$.

Comparison of the distribution in performance of examined competence by gender shows such trends: In digital competence bellow average performance in women occurred in $67 \%$ of cases, in men is only $50 \%$. Above-average performance in digital competence has only $3 \%$ of women compared with $15 \%$ of men.

Differences in competencies in terms of study specialization and gender 
Another objective was to identify differences in the digital competence due gender and field of study. The significance of differences in terms of study specialization and gender (see table 2) were considered by nonparametric methods because the data obtained on examined competencies were not normally distributed (Kolmogorov Smirnov's test probability values ranged from $\mathrm{p}<0.01$ to $\mathrm{p}<0.05)$.

Table 2 Significance of difference in digital competence by study orientation and gender (Kruskal-Wallis ANOVA)

\begin{tabular}{lccccc}
\hline Competence & \multicolumn{2}{c}{$\begin{array}{c}\text { Study } \\
\text { specialization }\end{array}$} & \multicolumn{2}{c}{ Gender } \\
& $\mathrm{H}$ & $\mathrm{p}$ & $\mathrm{H}$ & $\mathrm{p}$ \\
Digital competence & 19,71 & $0,0001^{*}$ & 2,62 & 0,1053 \\
\hline * Difference is statistically significant. & &
\end{tabular}

We have found the significant differences in terms of field of study in the level of digital, competence. Kruskal-Wallis ANOVA values were statistically significant ( $\mathrm{p}<0.0001$ ). Post hoc analysis was used to ascertain the direction of differences in mean values measured at digital competence. The study shows that the best performance in the digital competence is in the group of students of economic specialization, while gender differences were observed only in students of philosophical study specialization $(\mathrm{p}<0.02)$.

\section{Procedure for measuring the level of competence}

\section{Fuzzy Comprehensive Evaluation on Enterprise Core Competence}

1. Establishing concourse of evaluation factors

2. Establishing concourse of weight

3. Establishing concourse of comment

4. Establishing evaluation matrix

5. Proceeding to multilevel fuzzy comprehensive evaluation

6. Calculating comprehensive evaluation concourse of target layer

7. Calculating comprehensive evaluation worth

1. Establishing concourse of evaluation factors

Concourse of evaluation factors are as following:

$A=\left\{A_{1}, A_{2}, \ldots, A_{n}\right\}$, where $n$ is the number of evaluation factors; 
$A_{i}=\left\{A_{i 1}, A_{i 2}, \ldots, A_{i n_{i}}\right\}$, where $n_{i}$ is the number of evaluation subfactors for each factor $A_{i}$, $i=1,2, \ldots, n$.

$A_{i j}=\left\{A_{i j 1}, A_{i j 2}, \ldots, A_{i j n_{i j}}\right\}$, where $n_{i j}$ is the number of evaluation subsubfactors for each subfactor $A_{i j}, j=1,2, \ldots, n_{i} ; i=1,2, \ldots, n$.

2. Establishing concourse of weight

The weight $W_{A}\left[W_{A_{i}}, i=1, \ldots, n\right]\left[\left[W_{A_{i j}}, j=1, \ldots, n_{i} ; i=1, \ldots, n\right]\right]$ of each of the factors $A_{i} \in A$, $i=1,2, \ldots, n \quad$ [subfactors $\left.\quad A_{i j} \in A_{i}, j=1, \ldots, n_{i}, \quad i=1,2, \ldots, n\right], \quad$ [[subsubfactors $\left.\left.A_{i j k} \in A_{i j}, k=1, \ldots, n_{i j} ; j=1, \ldots, n_{i} ; i=1,2, \ldots, n\right]\right]$, is calculated using Analytic Hierarchy Process (AHP), where $\quad W_{A}=\left(a_{1}, a_{2}, \ldots, a_{n}\right), \quad\left[W_{A_{i}}=\left(a_{i 1}, a_{i 2}, \ldots, a_{i n_{i}}\right), i=1,2, \ldots, n\right]$, $\left[\left[W_{A_{i j}}=\left(a_{i j 1}, a_{i j 2}, \ldots, a_{i j n_{i j}}\right), j=1,2, \ldots, n_{i} ; i=1,2, \ldots, n\right]\right]$.

3. Establishing concourse of comment

Comment is qualitative description on good or bad of evaluation object. It becomes nonfigurative data to evaluation language that people know well. Concourse of comment is consistent to each layer of index. Let's denote (formally) the set $P$ as a set of characters $P=\left\{Z_{1}, Z_{2}, \ldots Z_{m}\right\}$, where $m$ is the number of the using evaluation language data and each of $Z_{i}, \quad i=1,2, \ldots m$ represents one of the evaluation language data. Next, the corresponding concourse of comment power coefficient matrix is $G=\left(g_{1}, g_{2}, \ldots, g_{m}\right) ; g_{1}>g_{2}>\ldots>g_{m}$. Most frequently $m=5$, then the set $P$ is normally given as $P=\{$ very good, good, general, bad, badly $\}$ and the corresponding concourse of comment power coefficient matrix is normally coded as $G=(9,7,5,3,1)$.

4. Establishing evaluation matrix

Evaluation matrix is fuzzy matrix result from fuzzy mapping. It means a comprehensive result that experts investigate. Let's denote this matrix as $R_{i j}: n_{i j} x m$ (it means, $R_{i j}$ is a matrix, consist from $n_{i j}$ lines and $m$ rows), $j=1,2, \ldots, n_{i} ; i=1,2, \ldots, n$.

5. Proceeding to multilevel fuzzy comprehensive evaluation

Fuzzy comprehensive evaluation matrix $E_{i}: n_{i} x m, i=1,2, \ldots, n$ is constructed. Beginning from the top level, proceeding to comprehensive evaluation to each layer every kind of index, i.e. each row of matrix $E_{i}: E_{i j}=W_{A_{i j}} x R_{i j} ;\left(E_{i j}: 1 x m\right), j=1,2, \ldots, n_{i}$. Next, fuzzy comprehensive evaluation matrix $F: n x m$ is constructed (similarly). Each row of matrix $F: F_{i}=W_{A_{i}} x E_{i}$; $\left(F_{i}: 1 x m\right), i=1,2, \ldots, n$.

6. Calculating comprehensive evaluation concourse of target layer

Fuzzy comprehensive evaluation target matrix B is constructed as a product $W_{A}$ of the weight concourse of target $A$ and the fuzzy comprehensive evaluation matrix $F$, i.e.: $B=W_{A} x F$; $(B: 1 x m)$. 
7. Calculating comprehensive evaluation worth

$X=B x G^{T}$. If $X \geq g_{1}$, then enterprise core competence correspond to the best evaluation language data $Z_{1}$; if $g_{i+1} \leq X \leq g_{i}, i=1,2, \ldots, m-1$; then enterprise core competence correspond to the evaluation language data between $Z_{i+1}$ and $Z_{i}$; if $X \leq g_{m}$, then enterprise core competence correspond to the worse evaluation language data $Z_{m}$.

\section{Discussion}

In our study we have shown a relatively low level of digital competence. The other significant finding was various levels of this competence according the study specialization and gender. These findings appear to be unexpected. Our assumption was based on belief that university students have to be more competent group in comparison with lower education level population group. The comparison with other relevant findings is not available now. In spite of the fact that many writers are dealing with competence topic their approaches are superficial. They are focusing only on speculations on this popular topic or they are searching only attitudes or opinions concerning the competencies. Some researchers analyzed specific issues, for example the competencies of medical students and doctors (Hojat, M. et al. 2007) or competencies in information technologies and business (Kollmann, T., Häsel, M., and Breugst, N., 2009).

Conducted research to probe the level and quality of digital competence highlighted the low level of this key competence for lifelong learning and knowledge society in a group of Slovak students, graduates of economic, philosophical and technical study specialization. This result is unsettling in terms of strategic objectives which the European Union, as well as our central authorities - Government of the Slovak Republic and the Slovak Ministry of Education - in its fundamental documents considered to be the priorities vital for achieving the objectives of a knowledge society.

\section{CONCLUSIONS}

The detection of level of management skills can help construction companies to know their strengths and weaknesses. This will allow better use of its available resources and improve its competitiveness in the building market. Determination of the core competencies allows the measurement of the level of individual activities, which is essential for a construction company success. In addition, competencies help to clarify behavior supporting the business values. Determination of core competencies to be developed and improved at all school levels and types of the SR, as well as for lifelong learning requires an extensive research in particular to identify key knowledge, skills and abilities, attitudes and value system that require core competencies of graduates.

\section{Acknowledgment}

Preparation of this paper was supported by Contract of the Ministry of Education of Slovak Republic under Project No. Req-00073-0001: Identification of key competences of university students required for development of knowledge society in Slovakia 


\section{REFERENCES}

Education Council (2006). Recommendation of the European Parliament and the Council of 18 December 2006 on key competencies for lifelong learning (Brussels, Official Journal of the European Union), 30 December.

Hojat, M. Paskin, D. L., Callahan C. A., Nasa, T.J., Louis, D. Z., Veloski, J., Erdmann, J.B. And Gonnella J.S. (2007). Components of postgraduate competence: analyses of thirty years of longitudinal data. Medical Education 2007: 41: 982-989

Kollmann, T., Häsel, M., \& Breugst, N. (2009). Competence of IT Professionals in E-Business Venture Teams: The Effect of Experience and Expertise on Preference Structure. Journal of Management Information Systems, 25(4), 51-79.

Mesároš, F. (2010) The detection level of competence building companies. In: Eurostav, 16 (3), 56-57.

Mesárošová, M., Mesároš, P., Mesároš, F. (2009a) Key competencies for the knowledge society I: Analysis of theoretical models and approaches. In: Economics and Business Management, 7 (2), 5-20.

Mesárošová, M., Mesároš, P., Mesároš, F. (2009b) Key Competences for Knowledge Society II: Analysis of the level of cognitive skills. In: Economics and Business Management, 7(2), 21-26.

Saaty, T. L., Tran, L. T.: On the invalidity of fuzzifying numerical judgments in the Analytic Hierarchy Process. Mathematical and Computer Modelling, vol. 46, 2007, 7 - 8, pp.

$962-975$. 